\title{
SLOBODA KRETANJA LJUDI ZA VRIJEME „PRVOG TALASA" PANDEMIJE IZAZVANE VIRUSOM KORONA U DRŽAVAMA ČLANICAMA EVROPSKE UNIJE
}

\begin{abstract}
Marija S. MILOŠEVIĆ*
Apstrakt: Predmet istraživanja je stepen ograničenja pojedinih ljudskih prava u cilju zaštite zdravlja ljudi i njihova opravdanost. Rad se fokusira na ispitivanje stepena ograničenja slobode kretanja ljudi u periodu od marta do juna 2020. godine. Bez obzira na izvanrednost situacije, ograničenja ljudskih prava moraju ispunjavati uslove zakonitosti, proporcionalnosti i neophodnosti u demokratskom društvu. Sa druge strane, mogućnost derogacije prava koristi se isključivo tokom vanrednih stanja, i u najnužnijoj mjeri koju takva situacija iziskuje. Autor ispituje uslove ograničenja, sa aspekta korelacije načela na kojima se zasniva koncept ljudskih prava, prije svega načela ograničenja i načela zabrane zloupotrebe ljudskih prava, kao i odstupanja od ljudskih prava u smislu posebnog vida ograničenja. Stepen slobode kretanja ljudi tokom aktuelne pandemije ispitujemo dalje u odnosu na sprovođenje restriktivnih mjera u državama članicama Evropske unije, i mjerimo opravdanost takvih mjera ali i legitimnost samog cilja koji se ogleda $u$ zaštiti javnog zdravlja.

Ključne riječi: virus korona, zaštita ljudskih prava, sloboda kretanja, Evropska unija, zaštita ljudskih prava, ograničenja sloboda, ograničavajuće mjere.
\end{abstract}

\section{1) UVOD}

Pandemija uzrokovana virusom korona otvorila je pitanje poštovanja ljudskih prava. ${ }^{1}$ Novi virus, koji se pojavio krajem 2019. godine u Kini, prevazišao je granice

\footnotetext{
* Autorka je doktorand Pravnog fakulteta Univerziteta u Beogradu, zaposlena u Sekretarijatu Odbora za evropske integracije Skupštine Crne Gore, Podgorica.

E-mail: marija.milosevic@skupstina.me.

${ }^{1}$ Naziv „virus korona” definisan je Odlukom Odbora za standardizaciju srpskog jezika od 4. feburara 2020. godine kao najispravniji.
} 
ove države i proširio se na ostale kontinente. Svjetska zdravstvena organizacija (SZO) zvanično je proglasila globalnu pandemiju 11. marta 2020. godine. Budući da nije poznat tačan način širenja virusa, a ni razmjera zaraze u državama nije bila jednaka, države su pozvane da se pripreme za različite scenarije zaštite javnog zdravlja. Ipak, usljed identifikovanja velikog broja oboljelih, ali i umrlih, vrlo brzo je postalo očigledno da je neophodno osigurati efikasne mehanizme prepoznavanja, kontrolisanja i zbrinjavanja zaraženih.

Odbor za bioetiku Savjeta Evrope kroz Saopštenje od 14. aprila 2020. godine ističe važnost poštovanja ljudskih prava prilikom donošenja odluka u vezi sa zaštitom zdravlja ljudi. U saopštenju se navodi da "načela ljudskih prava moraju biti ideja vodilja prilikom donošenja medicinskih odluka u kontekstu aktuelne krize". Pozivajući se na Konvenciju o zaštiti ljudskih prava i biomedicini (Konvencija u Ovijedu) odbor podsjeća, između ostalog, da „bilo kakva ograničenja u ostvarivanju prava treba da budu propisana zakonom i usmjerena ka zaštiti kolektivnih interesa, uključujući javno zdravlje". ${ }^{2}$ Opravdanost mjera preduzetih u cilju što djelotvornije borbe protiv širenja bolesti na nivou Evropske unije (u daljem tekstu: EU) u prvom talasu pandemije biće predmet ispitivanja, prije svega sa aspekta poštovanja ljudskih prava u skladu sa regionalnim mehanizmima zaštite.

Smatra se da samim članstvom u EU država zadovoljava određeni kriterijum demokratičnosti i društveno-ekonomskog razvoja. Ipak, svjedoci smo da su u aktuelnoj krizi, države članice imale različite pristupe rješavanju problema. Ukoliko uzmemo u obzir istoriju funkcionisanja EU, to i nije toliko iznenađujuće. Posebno je u periodima kriza dolazio do izražaja različit pristup država članica problemima i izazovima, čak i kad su dovođeni u pitanje osnovni principi funkcionisanja same zajednice. Slobodan protok ljudi, robe, kapitala i usluga predstavlja temelj EU i dovođenje u pitanje slobode kretanja ljudi ima višeslojan uticaj na funkcionisanje zajednice.

S jedne strane, virus korona odrazio se na sve domene društvenog i privrednog života. Uslovi bolesti, kakva je Covid-19, čiji uzrok, širenje i prevencija još uvijek nisu dovoljno istraženi, predstavljaju kriznu situaciju u kojoj su demokratska društva u iskušenju, bez obzira na razvijenost. S druge strane, usklađeno djelovanje i ulaganje u ljudska prava jedan je od načina sprečavanja da društvo ne zapadne u krizu.

U nastavku ćemo pokušati da objasnimo u kojoj mjeri su ograničenja ljudskih prava, posebno slobode kretanja ljudi, bila opravdana i kakve sve posledice na demokratičnost društava takve mjere mogu proizvesti. Pravni osnov analize primarno leži u Evropskoj konvenciji za ljudska prava (u daljem tekstu: Konvencija)

2 „Saopštenje Savjeta Evrope o pitanjima zaštite ljudskih prava relevantnim za pandemiju COVID-19" (Council of Europe: COVID-19: Human rights principles must guide health decisions), Odbor za bioetiku, https://www.coe.int/en/web/portal/-/covid-19-humanrights-principles-must-guide-health-decisions, pristupljeno: 14. april 2020. godine. 
i Povelji Evropske unije o osnovnim pravima (u daljem tekstu: Povelja EU), kao krovnim instrumentima zaštite ljudskih prava na nivou država članica EU. Rad je podijeljen u tri cjeline. Na početku, autor se bavi pitanjem ograničenja ljudskih prava, posebno sa aspekta zaštite zdravlja na način kako to propisuju navedeni krovni dokumenti za regionalnu zaštitu ljudskih prava. U drugom dijelu, pažnja autora usmjerena je na ograničenje slobode kretanja ljudi za vrijeme pandemije i dilemu u pogledu odnosa slobode kretanja, slobode i bezbjednosti ličnosti, odnosno lišavanja slobode zarad legitimno postavljenog cilja. Četvrto poglavlje bavi se odgovorom institucija EU i vlada država članica na krizu i u kojoj mjeri je sloboda kretanja bila ograničena u odnosu na države članice.

\section{2) USLOVI OGRANIČENJA LJUDSKIH PRAVA I DEROGACIJE U CILJU ZAŠTITE ZDRAVLJA}

Kada govorimo o načelu ograničenja ljudskih prava razlikujemo fakultativna i inherentna ograničenja i odstupanje ili derogaciju ljudskih prava. ${ }^{3}$

Inherentna ili ugrađena ograničenja ljudskih prava ograničena su samom formulacijom garantovanog prava, kada se u samoj definiciji nabrajaju izuzeci i napominju situacije u kojima nije moguća zaštita određenog prava. Ili, u slučaju onih prava koji sami po sebi ne pripadaju svakom licu. Recimo, sloboda kretanja je ograničeno pravo lica u smislu ulaska na teritoriju države čiji on nije državljanin.

Sa druge strane, fakultativna ograničenja podrazumijevaju da država može ograničiti određena garantovana prava u cilju opšteg interesa i/ili u skladu sa potrebama i interesima strane ugovornice. ${ }^{4} \mathrm{U}$ skladu sa pravilima o fakultativnim ograničenjima ljudskih prava, ograničenja moraju biti propisana zakonom, moraju biti srazmjerna datom cilju i moraju odgovarati potrebi društva u cilju zaštite javnog poretka, zdravlja, bezbjednosti i morala. ${ }^{5}$

Smisao načela ograničenja, između ostalog, jeste „postizanje ravnoteže opštih interesa i interesa pojedinca", pod uslovom da su ona zakonita, neophodna i proporcionalna legitimnom cilju. ${ }^{6}$ Ahron Barak uslov zakonitosti tumači kao „odraz vladavine prava”, tvrdeći da osnov ograničenja leži u zakonu. ${ }^{7}$ Dalje, Stojanović smatra da mogućnost ograničenja „na osnovu zakona”, ,propisno zakonu”, ,, skladu

\footnotetext{
${ }^{3}$ Milan Paunović, Boris Krivokapić, Ivana Krstić, Međunarodna ljudska prava, Pravni fakultet Univerziteta u Beogradu, Beograd, 2015, str. 63-75.

${ }^{4}$ Aharon Barak, "Proportionality: Constitutional Rights and their Limitations", New York Cambridge University Press, 2012, pp. 133-144.

${ }^{5}$ Milan Paunović, Boris Krivokapić, Ivana Krstić, Međunarodna ljudska prava, op. cit., str. 69.

${ }^{6}$ Milan Paunović, Slavoljub Carić, Evropski sud za ljudska prava, Pravni fakultet Univerziteta u Beogradu, Beograd, 2007, str. 34.

${ }^{7}$ Aharon Barak, "Proportionality: Constitutional Rights and their Limitations", op. cit., p. 107.
} 
sa zakonom”, koju dopuštaju međunarodni instrumenti zaštite, „dozvoljavaju izvršnim i sudskim organima da realizuju ograničenje”. ${ }^{8}$ Pri tome, zakonski propisi kojima se vrši ograničenje moraju biti ,jasni, dostupni i predvidljivi".

Međutim, sama zakonitost ne utvrđuje granice ograničenja niti u krajnjoj mjeri njegovu opravdanost. Granice ograničenja zavise i od poštovanja „uslova proporcionalnosti”, odnosno „srazmjernosti ograničenja postavljenom cilju”. Kod razmatranja proporcionalnosti, analizirajući sudsku praksu, vidimo da je Evropski sud za ljudska prava (u daljem tekstu: ESLJP) zauzimao stav u odnosu na to da li je ispunjen „balans podnosioca prestavke i opšti interes u vidu javne politike, koji u konkretnom slučaju ima jaču snagu". ${ }^{10} \mathrm{U}$ poznatom slučaju Garib protiv Holandije, mjera je bila ograničena vremenski i prostorno, i kao takva prošla test proporcionalnosti. ${ }^{11}$ Konačno, ograničenje mora da bude odraz neophodnosti u društvu, uslovljeno obezbjeđivanjem nekog opšteg interesa i osnovne vrijednosti društva. Sudska praksa ukazuje da postoje kolebanja u pogledu primjene uslova ograničenja, u smislu ravnoteže slobode i stvarne potrebe društva. ${ }^{12}$

Prilikom procjene opravdanosti ograničenja, u smislu da li je neka država prekoračila dozvoljeni domet derogacije, u praksi ESLJP se primjenjuje tzv. „doktrina slobode procjene” (margin of appreciation), u skladu sa kojom organi nadležni za međunarodni nadzor postavljaju standarde na osnovu kojih se ispituje opseg diskrecionog prava države da suspenduje ili ograniči neke od zagarantovanih prava. ${ }^{13}$ To bi značilo da država ima diskreciono pravo da donese odluku o proglašenju vanrednog stanja i određena ljudska prava i slobode ograniči ili od njih odstupi. Međutim, takvo polje ne može biti neograničeno i sud daje ocjenu da li je određena aktivnost države bila u okviru njega u konkretnom slučaju. ${ }^{14}$

Iako ne postoji jasna definicija ove doktrine, pojedini autori je tumače kao „popuštanje Suda državi, naročito kada situacija diktira snažne argumente s jedne strane za opravdanost ograničenja, ali i mješanje države, s druge strane". ${ }^{15}$ Pravni

\footnotetext{
${ }^{8}$ Dejan Stojanović, Osnovna prava čoveka: ljudska prava i slobode u ustavima evropskih država, Institut za pravna i društvena istraživanja, Niš, 1989, str. 165.

${ }^{9}$ Milan Paunović, Boris Krivokapić, Ivana Krstić, Međunarodna ljudska prava, op. cit., str. 71.

${ }^{10}$ Garib protiv Holandije, predstavka br. 43494/09, presuda ESLJP od 23. februara 2016.

${ }^{11}$ Ivana Krstić, Tanasije Marinković, Evropsko pravo ljudskih prava, Savjet Evrope, Kancelarija u Beogradu, Beograd, 2016, str. 153.

${ }^{12}$ Vidjeti: Enhorn v. Švedske, predstavka br. 56520/00, presuda ESLJP od 25. januara 2005. godine.

${ }^{13}$ Milan Paunović, Boris Krivokapić, Ivana Krstić, Međunarodna ljudska prava, op. cit., str. 73.

${ }^{14}$ Nina-Louisa Arold Lorenz, Xavier Groussot, Gunnar Thor Petursson, The European Human Rights Culture - A Paradox of Human Rights Protection in Europe, Leiden, 2013, pp. 73-78.

${ }^{15}$ Karen Reid, "A practitioner's guide to the European Convention on Human Rights", Thomson/Sweet \& Maxwell, London, 2015, p. 59.
} 
osnov ograničenja u kontekstu zaštite zdravlja nalazimo u odredbama Konvencije i Povelje EU. „Zaštita javnog zdravlja” kao legitimni cilj ograničenja u Konvenciji propisana je u članovima 8, 9, 10 i 11 kao i članu 2 Protokola 4. Ograničenje sloboda u cilju „sprečavanja širenja zaraznih bolesti|” propisano je u članu 5 Konvencije. ${ }^{16}$

Smatra se da legitimni cilj podliježe uskom tumačenju zbog toga što ovako postavljene odredbe predstavljaju izuzetak od opšteg pravila kojim se pruža zaštita pojedinom pravu. ${ }^{17}$ Sa druge strane, teorija poznaje listu legitimnih ciljeva koja je dovoljno široko propisana da obuhvati sve aktivnosti država. ${ }^{18}$ Kao razlog tome neki autori ističu da nijedna država ne želi da odgovara zbog unošenja proizvoljnih ciljeva u nacionalni normativni okvir, kao i to da ESLJP najčešće ocjenjuje ispunjenost ovog uslova zajedno sa drugim elementima proporcionalnosti. ${ }^{19}$ Drugim riječima, Sud će ocjenjivati da li su mjere bile adekvatne za postizanje cilja koji se želi postići, ${ }^{20}$ da li je ograničavajuća mjera bila neophodna u smislu da li se manje restriktivna mjera mogla primijeniti za postizanje istog rezultata i, konačno, da li postoji balans između prava koja su u suprotnosti i interesa. ${ }^{21}$

U odnosu na Konvenciju, Povelja EU propisuje da svako ograničenje primjene prava mora biti predviđeno zakonom, a dopuštena su ukoliko su neophodna i „istinski zadovoljavaju ciljeve od opšteg interesa koje priznaje Unija ili potrebu zaštite prava i slobode drugih" (čl. 52, st. 1 Povelja EU). ${ }^{22}$ Važno je napomenuti da se prava propisana Poveljom tumače u skladu sa ustavnom tradicijom država članica, što dalje implicira da je stepen primjene ograničenja u korelaciji sa implementacijom u odnosu na nacionalno zakonodavstvo. ${ }^{23}$

\footnotetext{
${ }^{16}$ „Evropska konvencija o ljudskim pravima i slobodama sa izmjenama predviđenim Protokolima br. 11 i 14 sa Protokolima br. 1, 4, 6, 7, 12, 13 i 16", Evropski sud za ljudska prava, Savjet Evrope F-67075 Strasbourg cedex, 2013, dostupno na: https://www.echr.coe. int/Documents/Convention_MNE.pdf, pristupljeno: 14. april 2020. godine.

${ }^{17}$ Vidjeti: Perinçek v. Switzerland, predstavka br. 27510/08 presuda ESLJP od 15. oktobra 2015.

${ }^{18}$ William Schabas, The European Convention on Human Rights: A Commentary, Oxford, 2015, p. 404.

${ }^{19}$ Yutaka Arai-Takahashi, The Margin of Appreciation Doctrine and the Principle of Proportionality in the Jurisprudence of the ECHR, Antwerpen - Oxford - New York, 2001, p. 11.

${ }^{20}$ Juan Cianciardo, "The Principle of Proportionality: The Challenges of Human Rights", 3 Journal of Civil Law Studies (2010), p. 184.

${ }^{21}$ Bernhard Schlink, "Proportionality" in: Rosenfeld Michel and Sajó András, (eds.), The Oxford Handbook of Comparative Constitutional Law, Oxford, 2012, Oxford University Press, pp. 718-737.

22 "Charter of Fundamental Rights of the European Union 2012/c 326/02", Official Journal of the European Union C 326/391, 26 October 2012, član 52, stav 1).

${ }^{23}$ Ibid., stav 4.
} 
Načelo ograničenja ljudskih prava samo je jedan od principa na kome se zasniva koncept ljudskih prava. Ovdje je važno ukazati i na načelo zabrane zloupotrebe prava i odstupanja od ljudskih prava. Načelo zabrane zloupotrebe prava, definisano članom 17 Evropske konvencije, utvrđuje granice ograničenja. ${ }^{24} \mathrm{U}$ kontekstu rada i ispitivanja opravdanosti ograničavajućih mjera, načelo zabrane zloupotrebe prava dovodi nas, takođe, u vezu sa mjerenjem opravdanosti u odnosu na ispunjavanje uslova zakonitosti i neophodnosti. Čini se da ovo načelo utvrđuje granice mogućim ograničenja u smislu da ono ne može da bude „veće” nego što je to propisano Konvencijom. Sa druge strane, ESLJP je u slučaju Tirer protiv Ujedinjenog Kraljevstva istakao da Konvencija predstavlja „živ instrument”, i prilikom tumačenja njenih odredaba valja uzeti u obzir okolnosti koje postoje u trenutku tumačenja, nezavisno od onoga što se željelo postići u momentu pisanja Konvencije. ${ }^{25}$

Dalje, u teoriji je poznato i odstupanje od ljudskih prava ili derogacija, kao poseban vid ograničenja u stanju državne nužde. Stojanović ističe da većina evropskih ustava dopušta djelimično suspendovanje i to za vrijeme vanrednog stanja, ratnog stanja ili druge javne opasnosti. Pritom, apsolutno zaštićena prava nije moguće derogirati ni u navedenim okolnostima, a budući da ne postoji jedinstvena lista apsolutnih prava u sklopu međunarodnih instrumenta zaštite, nije moguće utvrditi jasnu granicu ograničenja. ${ }^{26}$ Član 15 Konvencije glasi:

U doba rata ili druge javne opasnosti koja prijeti opstanku nacije, svaka Visoka strana ugovornica može da preduzme mjere koje odstupaju od njenih obaveza po ovoj Konvenciji, i to u najnužnijoj mjeri koju iziskuje takva situacija, s tim da te mjere ne budu u neskladu s njenim drugim obavezama prema međunarodnom pravu. ${ }^{27}$

U zvaničnim izjavama visokih predstavnika država i međunarodnih organizacija mogla se čuti upotreba riječi „rat” kao metafore kojom bi opisali ozbiljnost situacije i ukazali na važnost solidarnosti i empatije. ${ }^{28}$ Međutim, ova metafora može poslužiti

24 "Ništa u ovoj Konvenciji ne može se tumačiti tako da podrazumijeva pravo bilo koje države, grupe ili lica da se upuste u neku delatnost ili izvrše neki čin koji je usmjeren na poništavanje bilo kog od navedenih prava i sloboda ili na njihovo ograničavanje u većoj mjeri od one koja je predviđena Konvencijom" (čl. 17).

${ }^{25}$ Vidjeti: Tirer protiv UK (Tyrer v. the United Kingdom), predstavka br. 5856/72, presuda od 25. aprila 1978, paragraf 31.

${ }^{26}$ Dragan Stojanović, Ustavno pravo - knjiga I, Centar za publikacije Pravnog fakulteta u Nišu, Niš, 2009, str. 314.

27 „Evropska konvencija o ljudskim pravima i slobodama sa izmjenama predviđenim Protokolima br. 11 i 14 sa Protokolima br. 1, 4, 6, 7, 12, 13 i 16", Evropski sud za ljudska prava, Savjet Evrope, F-67075 Strasbourg cedex, 2013, dostupno na: https://www.echr. coe.int/Documents/Convention_MNE.pdf, str. 12.

${ }^{28}$ Vidjeti: "War Metaphors in Political Communication on Covid-19", izjave predsjednika Francuske, Portugala, predsjednice Evropske komisije, generalnog sekretara UN, dostupno na: https://doi.org/10.3389/fsoc.2020.583680, pristupljeno: 11. maj 2021. 
i kao političko opravdanje za primjenu ograničenja ljudskih prava. U prilog tome, iako Evropski sud za ljudska prava nije definisao pojam rata, postoji široko prihvaćena definicija Međunarodnog krivičnog suda za bivšu Jugoslaviju u slučaju Tadić koja glasi: „oružani sukob postoji kad god postoji pribjegavanje oružanoj sili između država". ${ }^{29} \mathrm{U}$ tom smislu, čini se da međunarodno pravo isključuje karakterizaciju aktuelne krize kao „rat”.

Ipak, pandemija svjetskih razmjera mogla bi se smatrati ozbiljnom prijetnjom po čovječanstvo i ,javnom opasnosti” koja je uticala na svakodnevni život građana. Ovdje ćemo ukazati na sudsku praksu koja se odnosi na tumačenje člana 15 u cilju argumenata koji idu u prilog tvrdnji.

U slučaju Loles protiv Irske, u paragrafu 28, ESLJP je zauzeo stav da javna opasnost koja prijeti opstanku nacije predstavlja „izuzetnu situaciju krize ili opasnosti koja utiče na cjelokupno stanovništvo i predstavlja prijetnju za organizovani život zajednice". ${ }^{30}$ U slučaju Danska, Norveška, Švedska i Holandija protiv Grčke iz 1969. godine, ESLJP tumači opasnost kao „stvarnu”, ,intenzivnu” i „neophodnu” u slučaju da dopuštene mjere organičenja u cilju zaštite javne bezbjednosti i zdravlja nisu dovoljne da bi se opasnost uklonila. ${ }^{31}$

Postavlja se pitanje da li se aktuelna situacija, uzrokovana epidemiološkom krizom, može smatrati „stanjem državne nužde”, usljed čega su, u skladu sa Konvencijom, dopuštena odstupanja od ljudskih prava.

U praksi, ESLJP je zauzimao stav da je javna opasnost koja prijeti opstanku nacije, kao uslovu potvrde stanja državne nužde, opšta kriza koja utiče na svakodnevni život zajednice.

Aktuelna situacija, dakle, može se smatrati „stanjem javne opasnosti” koja prijeti opstanku nacije i shodno tome bi potencijalno mogla da ispunjava uslove iz člana 15 EKLJP. Međutim, u tom slučaju riječ je o derogaciji ljudskih prava, koja je moguća jedino pod uslovom proglašenja vanrednog stanja. ${ }^{32} \mathrm{U}$ tom slučaju, države su dužne ispuniti i jedan protokolarni uslov. U skladu sa stavom 3 člana 15 EKLJP, država je obavezna da obavjesti generalnog sekretara Savjeta Evrope o stanju nužde u pogledu pristupa derogacije naznačenih prava, sa napomenom vremenskog

${ }^{29}$ ICTY, The Prosecutor v. Dusko Tadic, Decision on the Defence Motion for Interlocutory Appeal on Jurisdiction, IT-94-1-A, 2 Oct., 1995, 70, https://www.icty.org/x/cases/tadic/acdec/en/ 51002.htm, pristupljeno 11. maj 2021.

${ }^{30}$ Lawless v. Ireland (No. 3) predstavka br. 332/57, 1961. godine.

${ }^{31}$ Vidjeti: The Greek case - Denmark v. Greece; Norway v. Greece; Sweden v. Greece; Netherlands v. Greece, https://hudoc.echr.coe.int/eng\#\{\%22itemid\%22:[\%22001-167795\%22]\}, pristupljeno 7. februara 2021. godine.

32 Dejan Pavlović, „,Doktrine Evropskog suda za ljudska prava”, Međunarodna politika, br. 1144, 2011, str. 69. 
perioda u kom će se derogacija primjenjivati. Na nivou EU u toku prvog talasa pandemije, do juna 2020. godine, notifikaciju su generalnom sekretaru uputile Rumunija, Estonija i Letonija. ${ }^{33}$ Zanimljivo je, na primjer, da Francuska koja je u periodu od 2015. do 2017. godine zbog terorističkih napada nekoliko puta upućivala notifikacije generalnom sekretaru, u ovom slučaju to nije uradila, iako je proglasila vanredno stanje i preduzela restriktivne mjere. ${ }^{34}$

Sa druge strane, Burton i dr. definišu derogaciju kao „racionalan odgovor na nesigurnost, omogućavajući vladama da kupuju vrijeme (...) u cilju prevazilaženja krize primjenom privremenog ograničenja političkih i građanskih sloboda". ${ }^{35}$

Osim toga, klauzule o odstupanju nisu, prema Geraldu L. Neumanu, u suprotnosti sa pojamom ljudskih prava, ali mogu doprinijeti njihovoj efikasnoj zaštiti. ${ }^{36} \mathrm{U}$ tom smislu, u skladu sa članom 2 Evropske konvencije, države su u obavezi da štite pravo na život, što opravdava derogaciju određenih prava i sloboda.

\section{3) OGRANIČENJA SLOBODE KRETANJA}

Sloboda kretanja neodvojiv je dio slobode ličnosti. Evropsko pravo slobodu kretanja propisuje na način da „svako ko se zakonito nalazi na teritoriji jedne države ima, na toj teritoriji, pravo na slobodu kretanja i slobodu izbora boravišta", što podrazumijeva nesmetano cirkulisanje pojedinca na teritoriji na kojoj zakonito boravi, bez obzira da li se radi o državljaninu date države ili strancu (Protokol 4, čl. 2 Konvencije). Član 2 stav 2 Protokola 4 Konvencije propisuje ograničenja „koja su uvedena u skladu sa zakonom i opravdana javnim interesom u demokratskom društvu". ${ }^{37}$

\footnotetext{
${ }^{33}$ Notifikacije država u odnosu na primjenu člana 15 Evropske konvencije u kontekstu pandemije dostupne na: https://www.coe.int/en/web/conventions/full-list/-/conventions /webContent/62111354, pristupljeno: 7. februar 2021.

${ }^{34}$ Vidjeti: Izvještaj "When a Temporary State of Emergency becomes Permanent: France as a Case Study”, dostupan: https://www.tni.org/files/publication-downloads/france_and_ the_states_of_emergency_online.pdf, pp. 12-14, pristupljeno: 11. maj 2021.

${ }^{35}$ Emilie M. Hafner-Burton et al. "Emergency and Escape: Explaining Derogations from Human Rights Treaties", in International Organization, Vol. 65, Cambridge University Press, 2011, pp. 680.

${ }^{36}$ Gerald L. Neuman, “Constrained Derogation in Positive Human Rights Regime”, in Evan J. Criddle (ed.), Human Rights in Emergencies, pp. 15-31.

37 „Evropska konvencija o ljudskim pravima i slobodama sa izmjenama predviđenim Protokolima br. 11 i 14 sa Protokolima br. 1, 4, 6, 7, 12, 13 i 16", Evropski sud za ljudska prava, Savjet Evrope, F-67075 Strasbourg cedex, 2013, dostupno na: https://www.echr. coe.int/Documents/Convention_MNE.pdf, str. 34.
} 
Povelja EU „ograničava” slobodu na državljanstvo neke od članica EU i u članu 45 propisuje da "građanin Unije ima pravo da se slobodno kreće i nastani na teritoriji država članica”, dok se za državljane trećih država „odobrava sloboda kretanja u skladu sa Ugovorima. Osim toga, sloboda kretanja, u skladu sa Poveljom EU, podrazumijeva i pravo pojedinca da napusti zemlju u kojoj se nalazi.

\subsection{SLOBODA KRETANJA vs. LIŠAVANJE SLOBODE}

Slobodu kretanja valja razlikovati od prava pojedinca da ne bude lišen slobode. ${ }^{38}$ Ovdje ćemo pokušati ukazati na odnos ove dvije kategorije prava/sloboda.

Član 5 Konvencije u stavu 1 propisuje da niko ne može biti lišen slobode osim u određenim slučajevima i u skladu sa zakonom propisanim postupkom. Među situacijima u kojima je moguće pojedinca lišiti slobode navodi se slučaj zakonitog lišenja slobode da bi se spriječilo širenje zaraznih bolesti. ${ }^{39}$ Ovdje bi trebalo ukazati na različitu pravnu prirodu fakultativnog ograničenja (na primjer slobode kretanja) i inherentnog ograničenja prava na slobodu i bezbjednosti ličnosti. Naime, inherentna ograničenja podrazumevaju situacije u kojima nema ograničenja prava u pravom smislu riječi, već se radi o numerus clausus nabrojanim odstupanjima, situacijama koje se prema samoj Konvenciji neće smatrati povredom prava. Ipak, Sud će u praksi vršiti analizu i procjenu da li se konkretno činjenično stanje može podvesti pod neko od odstupanja, čak će primjenjivati i određeni oblik testa proporcionalnosti, ali se to razlikuje od fakultativnih ograničenja.

Da li je u vrijeme pandemije legitimno ograničena sloboda kretanja, i/ili su lica lišena slobode? Kakav bi bio stav Evropskog suda za ljudska prava u slučaju potencijalne povrede prava, odnosno kakva bi u tom slučaju bila mogućnost sudske zaštite?

\footnotetext{
${ }^{38}$ Ivana Krstić, Tanasije Marinković, Evropsko pravo ljudskih prava, op. cit., str. 153.

${ }^{39}$ Član 5 Konvencije stav 1: „Niko ne može biti lišen slobode sem u slučajevima:

- da se radi o zakonitom lišenju slobode na osnovu presude nadležnog suda;

- u slučaju zakonitog hapšenja ili lišenja slobode zbog neizvršenja zakonite sudske odluke ili radi obezbjeđenja ispunjenja neke zakonom propisane obaveze;

- u slučaju zakonitog hapšenja ili lišenja slobode radi privođenja lica pred nadležnu sudsku vlast zbog opravdane sumnje da je izvršilo krivično djelo, ili kad se to opravdano smatra potrebnim radi sprečavanja izvršenja krivičnog djela ili bekstva nakon njegovog izvršenja;

- u slučaju lišenja slobode maloletnog lica na osnovu zakonite odluke u cilju vaspitnog nadzora ili zakonitog lišenja slobode radi privođenja nadležnom organu;

- u slučaju zakonitog lišenja slobode lica radi sprečavanja širenja zaraznih bolesti, kao i zakonito lišenje slobode duševno poremećenih lica, alkoholičara, narkomana i skitnica;

- u slučaju zakonitog hapšenja ili lišenja slobode lica u cilju sprečavanja njegovog ulaska u zemlju ili protiv lica u postupku ekstradicije ili deportacije."
} 
U skladu sa principom neposredne primjene ljudskih prava organi nadležni za zaštitu prava se u svojim odlukama pozivaju na ustavne odredbe, ili norme međunarodnih ugovora kojima se propisuje zaštita. Član 5 Konvencije ne definiše lišavanje slobode, što znači da će se ono ispitivati u konkretnom slučaju. Zbog toga je od presudnog značaja sudska praksa u ovoj oblasti.

Vidjeli smo da, u skladu sa međunarodnim normama, širenje zarazne bolesti može biti osnova za lišavanje slobode. Međutim, postoje dva bitna kriterijuma za zakonito lišavanje slobode koja je potrebno ispuniti:

- da li je širenje zarazne bolesti opasno za javno zdravlje ili bezbjednost;

- da li je lišavanje slobode krajnja mjera kako bi se spriječilo širenje bolesti, jer su razmotrene manje teške mjere, te je utvrđeno da su nedovoljno efikasne za zaštitu javnog interesa. ${ }^{40}$

U poznatom slučaju Enhorn protiv Švedske iz 2005. godine, Evropski sud je zaključio da kada ovi kriterijumi nisu ispunjeni prestaje da postoji osnov za lišavanje slobode. ${ }^{41}$

Podnosilac predstavke Enhorn je lice pozitvno na HIV virus. Nakon što je preneo virus drugom licu, okružni zdravstveni inspektor mu je, u skladu sa švedskim Zakonom o zaraznim bolestima iz 1988, izdao mjere koje su, između ostalog, podrazumijevale i redovan dolazak na sastanke koje je zdravstveni inspektor ugovarao. Nakon što se nije pojavio na pet zakazanih sastanaka, čime je prekršio izdate mjere, Okružni sud je podnosiocu predstavke donio presudu da se pomenutom licu odredi prinudna izolacija u cilju sprečavanja širenja zaraznih bolesti do tri mjeseca, na osnovu Zakona o zaraznim bolestima. Podnosilac predstavke žalio se na povredu prava garantovanih u članu 5 Konvencije, zbog prinudne izolacije i kasnije hospitalizacije protiv njegove volje. U navedenom slučaju, ESLJP je zaključio da je došlo do povrede člana 5, a u izdvojenom mišljenju sudija Kosta navodi da ovaj slučaj ilustruje ne samo „ravnotežu između slobode i potreba društva”, nego i određen stepen „kolebanja” u pogledu zaštite od kriterijuma zakonitosti i neophodnosti. ${ }^{42}$ Vezu zakonitosti i neophodnosti nalazimo u članu 17 Konvencije, koji glasi:

„Ništa u ovoj Konvenciji ne može se tumačiti tako da podrazumijeva pravo bilo koje države, grupe ili lica da se upuste u neku djelatnost ili izvrše neki čin usmjeren

\footnotetext{
${ }^{40}$ Vidjeti: „Vodič ESLJP u tumačenju čl. 5 EKLJP”, paragraf 101, Savjet Evrope/Evropski sud za ljudska prava, 2014, dostupan na www.echr.coe.int (Case-Law/Case-Law Analysis/CaseLaw Guides), str. 19.

${ }^{41}$ Vidjeti: Enhorn protiv Švedske (Enhorn v. Sweeden) predstavka br. 56520/00, presuda ESLJP od 25. januara 2005. godine.

${ }^{42}$ Mišljenje sudije Ž-P Koste, Enhorn v. Sweeden, stav 15, presuda dostupna: http://hudoc.echr.coe.int/eng?i=001-68077, pristupljeno 7. februar 2021. godine.
} 
na poništavanje bilo kog od navedenih prava i sloboda ili na njihovo ograničavanje u većoj mjeri od one koja je predviđena Konvencijom. ${ }^{443}$

Ako bismo navedeno pokušali primjeniti na slučaj pandemije uzrokovane virusom korona, prvi kriterujum je ispunjen. Virus korona, prema navodima SZO, predstavlja novi virus koji uzrokuje bolest, čija se klinička slika manifestuje od "lakše” prehlade do ozbiljnih upala respiratornih organa i drugih medicinskih komplikacija sa kobnim ishodom. Iako nije dovoljno istražen izvor zaraze, zvanični izvještaji SZO ukazuju da se virus prenosi kapljičnim putem ili dodirivanjem površina kontaminiranih virusom. Prema zvaničnim informacijama SZO, na dan 10. maja 2020. godine, broj oboljelih iznosio je 3.884.434 stanovnika u 215 država svijeta, od čega je umrlo 272.859 ljudi. ${ }^{44}$ Dakle, riječ je o bolesti čije širenje jeste opasno po javno zdravlje.

Za razliku od prvog kriterijuma, čije ispunjavanje je očigledno i u prilog kome ide činjenica da se radi o svjetski opravdanoj pandemiji, drugi kriterijum lišavanja slobode, kao krajnje mjere u cilju sprečavanja širenja epidemije, može izazvati dileme. U navedenom slučaju, Sud se izjašnjavao o situaciji u kojoj se osobi koja je nosilac virusa (dakle opasnost) ograničava kretanje kako bi se zaštitili drugi ljudi, dok mi u aktuelnoj situaciji epidemiološke krize svjedočimo ograničenju kretanja i zdravih ljudi da bi ih zaštitili, pa se postavlja pitanje da li bi član 5 EKLJP tako nešto uopšte dozvolio.

Ipak, preduzimanje mjera u cilju sprečavanja širenja virusa svakako je bilo neophodno, jer je rizik po zdravlje ljudi bio očigledan. Ono što izaziva dilemu jeste da li su te mjere bile krajnje ili neophodne, odnosno da li su razmatrane manje restriktivne mjere ili su razmjere epidemije, alarmantna situacija po broju oboljelih i umrlih bili dovoljni razlozi da države odmah posegnu za najrestriktivnijim mjerama lišavanja slobode (napuštanje objekata stanovanja uz posebne dozvole i/ili tačno utvrđenim terminima u toku dana). ${ }^{45}$ Ili, može li lišavanje slobode baš zbog neophodnosti zaštite i rizika od zaraze, ali i širenja zaraze, biti shvaćeno kao krajnja mjera ograničavanja slobode kretanja?

ESLJP se veoma detaljno bavio razgraničenjem između lišenja slobode i ograničenja slobode kretanja. Iako je to često teško razdvojiti, očigledno je da zaštita

43 „Evropska konvencija o ljudskim pravima i slobodama sa izmjenama predviđenim Protokolima br. 11 i 14 sa Protokolima br. 1, 4, 6, 7, 12, 13 i 16", Evropski sud za ljudska prava, Savjet Evrope, F-67075 Strasbourg cedex, 2013, dostupno na: https://www.echr. coe.int/Documents/Convention_MNE.pdf, str. 13.

${ }^{44}$ Zvanični sajt Svjetske zdravstvene organizacije: https://www.who.int/emergencies/ diseases/novel-coronavirus-2019, pristupljeno 10. maj 2020. godine.

${ }^{45}$ Npr. Grčka, Francuska, Italija, Španija. Vidi: “Coronavirus pandemic in the EU - Fundamental Rights Implications", European Union Agency for Fundamental Rights, Luxembourg, Publications Office of the European Union, februar-mart 2020, p. 17. 
koju pruža član 5 i član 2 Protokola 4 nije ista. U predmetu Guzardi protiv Italije, Sud je jasno istakao da "razlika nije u prirodi mjere, već u stepenu odnosno intenzitetu mjere" i uzeo je u obzir: oblast u kojoj je kretanje ograničeno, obim društvenih kontakata koji su dozvoljeni, mogućnost da lice napusti mjesto bez obavještavanja nadležnih organa i sankciju u slučaju nepoštovanja obaveze. ${ }^{46}$

Važan je i predmet Noland i K. protiv Rusije, u kome je Sud istakao da se „ograničenje kretanja i od nekoliko sati može smatrati lišenjem slobode, što će se cjeniti na osnovu kriterijuma kao što su: da li je ustanova zatvorenog tipa; da li je bilo elemenata prinude; da li je mjera imala poseban efekat na pojedinca" (u smislu da je prouzrokovala fizičku nelagodnosti ili duševni bol). ${ }^{47}$

Iako navedena argumentacija na osnovu sudske prakse ide u prilog tvrdnji da u aktuelnoj epidemiološkoj situaciji prije možemo govoriti o lišavanju slobode nego o zabrani kretanja, na osnovu člana 5 lišenje slobode ne bi trebalo da bude preventivnog karaktera, dok ograničenje slobode kretanja može biti prevencija.

Međutim, u krajnjem, ovaj zaključak bi valjalo dodatno ispitati. Zabrana slobode kretanja izrečena i zdravim i zaraženim ljudima ukazuje na mogućnost date mjere kao prevencije. Da li su, uzimajući u obzir intenzitet zaraze ali i druge okolnosti (mjere izrečene zdravom ili zaraženom licu), mjere prevencije bile neophodne ili je bilo prostora za moguće zloupotrebe? Činjenica da je način širenja virusa nedovoljno istražen, uz postojanje očiglednih indikatora koji ukazuju da aktuelna kriza predstavlja prijetnju po život ogromnog broja ljudi, otežava izođenje konačnog zaključka u smislu odnosa lišavanja slobode i zabrane kretanja. Ipak, moguće je govoriti o lišavanju slobode kao krajnje mjere u ograničavanju slobode kretanja, a ne prevencije.

ESLJP u „Vodiču o tumačenju člana 5 Evropske konvenije” zauzima stav da kontekst u kojem se mjera preduzima predstavlja važan činilac, budući da su moguće situacije u kojima javnost „može biti pozvana da trpi ograničenja slobode kretanja ili slobode u interesu opšteg dobra" ${ }^{48}$ Zbog toga će i konačno tumačenje zavisiti od okolnosti u konkretnom slučaju.

U narednom dijelu rada pokušaćemo prikazati na koji način je EU odgovorila na krizu izazvanu virusom korona. Predstavljajući aktivnosti država članica u borbi

\footnotetext{
${ }^{46}$ Vidjeti: Guzardi protiv Italije (Guzzardi v. Italy), predstavka br. 7367/76, presuda od 6. novembra 1980, http://hudoc.echr.coe.int/eng?i=001-57498, pristupljeno: 7. februar 2021.

${ }^{47}$ Vidjeti: Noland i K. protiv Rusije (Noland and K. v. Russia), predstavka br. 2512/04, presuda od 12. februara 2009, http://hudoc.echr.coe.int/eng?i=001-91302, pristupljeno: 7. februar 2021.

48 „Vodič ESLJP u tumačenju čl. 5 EKLJP”, paragraf 6. Vidi još: De Tomaso protiv Italije (De Tomasso v. Italy) predstavka br. 43395/09); Nada protiv Švajcarske (Nada v. Switzerland) predstavka br. 10593/08); Ostin i drugi protiv Ujedinjenog Kraljevstva (Austin and others v. The United Kingdom) predstavke br. 39692/09, 40713/09 i 41008/09).
} 
protiv epidemiološke krize, sa fokusom na međudržavnu i međuinstitucionalnu koordinaciju, namjera autora je da ukaže na uticaj aktuelne krize na slobodu kretanja na nivou EU i moguće posledice preduzetih mjera u cilju suzbijanja širenja zaraze.

Ograničićemo se na ispitivanje mjera sa aspekta zaštite ljudskih prava i njihove opravdanosti u kontekstu vladavine prava. Međutim, bilo bi zanimljivo dalje ispitivati uticaj opravdanosti mjera za suzbijanje pandemije sa aspekta samog odnosa među državama članicama, sa nivoa promovisanja evropskih vrijednosti, ali i veze nacionalnog suveriniteta i poštovanja evropskog prava.

\section{4) SLOBODA KRETANJA NA NIVOU EU U USLOVIMA PRVOG TALASA PANDEMIJE}

Sloboda kretanja ljudi jedna je od četiri slobode na kojima se temelji Evropska unija. ${ }^{49}$ Kretanje u okviru Šengen zone i jedinstvenog evropskog tržišta regulisano je evropskim, a ne nacionalnim pravom. Direktiva 2004/38/EZ Evropskog parlamenta i Savjeta (čl. 27-33), propisuje da države članice mogu ograničiti slobodu kretanja iz razloga javnog zdravlja, bezbjednosti i poretka, ukoliko se ograničenje ne vrši „u ekonomske svrhe". ${ }^{50}$ Član 29 stav 1 pomenute Direktive propisuje da:

Jedine bolesti koje opravdavaju mjere kojima se ograničava sloboda kretanja jesu potencijalno epidemiološke bolesti, kako su utvrđene mjerodavnim instrumentima Svjetske zdravstvene organizacije, te druge zarazne bolesti ili zarazne bolesti čiji su uzročnici paraziti, ako protiv tih bolesti država članica domaćin donosi mjere za zaštitu svojih državljana. ${ }^{51}$

Na nivou Evropske unije (EU) institucije su donijele niz smjernica za koordinisano djelovanje u borbi protiv virusa korona. „Globalni odgovor na Covid19" zasnovan je na principu Tima Evrope (Team Europe). ${ }^{52}$ Ovaj princip podrazumijeva pomoć država članica koje su zajedno sa finansijskim institucijama

\footnotetext{
${ }^{49}$ Na nivou Unije regulisana je „Ugovorom o funkcionisanju EU” (čl. 21, čl. 45-66, glava 4 i čl. 67 Ugovora, „Ugovorom iz Mastrihta” (čl. 3, stav 2), kao i čl. 45 „Povelje o ljudskim pravima”.

50 "Directive 2004/38/EC of the European Parliament and of the Council of 29 April 2004", OJ, L 158/ 77, http://eur-lex.europa.eu/LexUriServ/LexUriServ.do?uri=0J:L:2004:158:00 77:0123:en:PDF, pristupljeno: 7. februar 2021.

${ }^{51}$ Ibid.

${ }^{52}$ Vidjeti: Saopštenje "Team Europe - Global EU Response to Covid-19 supporting partner countries and fragile populations", Služba EU za spoljne poslove, https://eeas.europa.eu /headquarters/headquarters-homepage/77470/\%E2\%80\%9Cteam-europe $\%$ E2\%80\% 9D-global-eu-response-covid-19-supporting-partner-countries-and-fragile-populations_en, pristupljeno: 11. april 2020. godine.
} 
EU, prvenstveno Evropskom bankom za razvoj i Evropskom bankom za obnovu i razvoj, osigurale paket od 20 milijardi evra namjenjenih članicama EU, ali i državama van granica EU.53 U zajedničkoj komunikaciji Evropske komisije (EK) i Visokog predstavnika za spoljne poslove i bezbjednosnu politiku, kao jedan od glavnih izazova navodi se garantovanje poštovanja ljudskih prava, posebno prava radnika, i demokratije. U „Komunikaciji o globalnom odgovoru na Covid-19” istaknuto je da „posebne i izvanredne mjere za sprečavanje širenja pandemije ne smiju dovesti do slabljenja temeljnih vrijednosti i načela otvorenih i demokratskih društava“.54

Zvaničnici država članica Evropske unije 10. marta 2020. godine organizovali su video konferenciju na kojoj su izrazili potrebu za zajedničkim pristupom i koordinacijom u cilju efikasne primjene restriktivnih mjera za suzbijanje epidemije na nivou država članica. U zaključcima je istaknuto da je zdravlje ljudi glavni prioritet, te da bi preduzete mjere trebalo da se zasnivaju na stručnim i medicinskim savjetima, i da budu srazmjerne kako ne bi imale pretjerane posledice na društvo u cjelini..$^{55}$

Sa druge strane, Izvještaj Agencije Evropske unije o ljudskim pravima ${ }^{56}$ sadrži opis mjera preduzetih na teritoriji država članica u prvom talasu pandemije. Nalazi Agencije potvrđuju ne samo različit pristup država u primjeni ograničavajućih mjera, već dovodi u pitanje poštovanje osnovnih sloboda za vrijeme pandemije. Međutim, ovdje je važno ukazati na značaj ispitivanja neophodnosti uvođenja i primjene ograničavajućih mjera, kao i mogućih zloupotreba.

Autori „Politika korona virusa i njegov uticaj na slobode i vladavinu prava u oblasti Šengena" ističu da su se mjere odnosile na: ponovno uvođenje graničnih kontrola od strane država članica; ograničenja ili zabrane međunarodnog prevoza putnika (obustava letova, prevoz vozova, ulazak automobilom ili autobusom, ulazak u luke iz svih ili određenih država), zabrane ulaska (tj. mjere zabrane ulaska pojedincima koji ne ispunjavaju određene uslove, kao što su prebivalište, koji se bave osnovnim uslugama kao što su prevoz robe i medicinske usluge). Državljani

${ }^{53}$ Ibid.

54 "Joint communication to the European Parliament, the Council, the European Economic and Social Committee and the Committee of the regions, European Commision and High Representative of the Union for Foreign Affairs and Security Policy, Brussels, 8.4.2020 JOIN(2020)", dostupna: https://ec.europa.eu/info/sites/info/files/joint_communication_ global_eu_covid-19_response_en.pdf, p. 2. pristupljeno: 11. april 2020. godine.

55 „Izjava predsjednika Evropskog savjeta povodom zaključaka od 7. maja 2020”, dostupna na: https://www.consilium.europa.eu/hr/presspress-releases/2020/03/10/statementby-the-president-of-the-european-council-following-the-video-conference-on-covid-19/, pristupljeno: 11. april 2020. godine.

${ }^{56}$ Vidjeti: Fundamental Rights Agency, https://fra.europa.eu/en/about-fra, pristupljeno: 11. april 2020. godine. 
država članica obično su izuzeti od takvih mjera. I konačno, zabrane izlaska iz države članice (tj. mjere zabrane izlaska osoba na sva putovanja koja nisu neophodna) koje su u prvom talasu primjenile Belgija, Češka i Litvanija. ${ }^{57}$ Vlade država članica kontrolisale su svoje granice bez koordinacije. Evropska komisija (EK) donijela je niz pravila i preporuka u cilju adekvatne primjene evropskog prava i koordinisanog djelovanja na nivou EU.

Međutim, koordinacija nije nužni zahtjev po evropskom pravu u okolnostima zaraznih bolesti i javne bezbjednosti. U skladu sa članom 28 Direktive 2004/38 država članica zadržava diskreciono pravo da djeluje različito, da se njihovo djelovanje može razlikovati od države do države, od perioda do perioda.$^{58} \mathrm{U}$ prilog tome, a prema mišljenju ESP od 13. decembra 1989. o pravnom efektu preporuka, iako preporuke nemaju obavezujući karakter, one se razmatraju od strane nacionalnih sudova, a imaju cilj da doprinesu jasnoj primjeni mjera ili pomognu pri primjeni obavezujućeg evropskog prava. ${ }^{59}$

Evropski savjet (ES) zvanično je prihvatio preporuke EK, kroz zajedničku izjavu članova ES od 26. marta 2020. godine.$^{60} \mathrm{U}$ izjavi je naglašena potreba djelovanja u cilju: suzbijanja širenja virusa, obezbjeđivanja neophodne medicinske opreme, promocije istraživanja i prevazilaženje novonastalih ekonomsko-socijalnih izazova, kao i povratak državljana EU koji su se zatekli u trećim državama u domovinu. U cilju očuvanja jedinstvenog tržišta, a u skladu sa smjernicama Komisije i Zakonom o Šengenu, ES je u usvojenom dokumentu od 26. marta ukazao na efikasno upravljanje granicama tamo gdje je uspostavljena privremena kontrola, i pozdravio uvođenje „zelenih traka” za brži prevoz robe u vanrednim okolnostima. ${ }^{61}$

\footnotetext{
${ }^{57}$ Sergio Carrera, Luk Ngo Chun, "Coronavirus politics and their impact on EU freedoms and rule of law in the Schengen Area", CEPS Policy Contribution, No. 2020-04, 2020, pp. 2-8.

58 "Directive 2004/38/EC of the European Parliament and of the Council of 29 April 2004 on the right of citizens of the Union and their family members to move and reside freely within the territory of the Member States amending Regulation (EEC) No 1612/68 and repealing Directives 64/221/EEC, 68/360/EEC, 72/194/EEC, 73/148/EEC, 75/34/EEC, 75/35/EEC, 90/364/EEC, 90/365/EEC and 93/96/EEC," OJ L 158, dostupna: https://eur-lex.europa.eu/ legal-content/EN/TXT/?uri=CELEX\%3A32004L0038, član 28, pristupljeno: 11. april 2020. godine.

${ }^{59}$ Judgment of the Court (second chamber) of 13 December 1989, case C-322/88, dostupna: https://eur-lex.europa.eu/resource.html?uri=cellar:bd89ea77-32ba-44d8-a1e0ec66779fc731.0002.03/DOC_2\&format=PDF, pristupljeno: 11. april 2020. godine.

60 "Joint statement of the Members of the European Council", dostupna: https://www. consilium.europa.eu/media/43076/26-vc-euco-statement-en.pdf, pristupljeno: 11. april 2020. godine.

${ }^{61}$ Ibid.
} 
U prvih šest mjeseci pandemije mapa restriktivnih mjera na teritoriji EU i dalje je zavisila od države do države. ${ }^{62} \mathrm{U}$ skladu s tim, mjere su podjeljene u nekoliko kategorija: zabrana okupljanja, zatvaranje prodavnica (sa izuzetkom onih koje prodaju hranu i osnovne životne namirnice), zabrana avio-saobraćaja, zabrana kretanja unutar države, zatvaranje škola, vrtića i drugih obrazovnih institucija, zabrana međunarodnog kretanja. U najvećem broju država Evropske unije mjere se primjenjuju u svim navedenim kategorijama mjestimično, u odnosu na određene djelove teritorije/regije. ${ }^{63}$

Ovdje je važno napomenuti da se članak odnosi na prvi talas pandemije, zbog čega je važno istaći da su u različitim periodima restriktivne mjere bile jače u jednim, a slabije u drugim državama članicama, kao i da su se vremenom mijenjale u skladu sa situacijom.

Mjere na nivou cijele teritorije u pogledu međunarodnog kretanja ljudi i zabrane avio-saobraćaja postojale su u: Španiji, Kipru, Litvaniji, Luksemburgu i Poljskoj. ${ }^{64}$ U prvom talasu pandemije najstrožije mjere bile su uvedene na Malti, koja je zabranila javna okupljanja, avio-saobraćaj i međunarodno kretanje, ali je djelimično ograničila kretanje ljudi unutar teritorije. ${ }^{65}$ Italija, koja je najviše pogođena država po broju oboljelih, zabranila je otvaranje škola, vrtića i drugih obrazovnih institucija, dok se restriktivne mjere u ostalim kategorijama i dalje djelimično primjenjuju. ${ }^{66}$

Države članice imale su različite strategije implementacije tih mjera. Tako, na primjer, prema nalazima Agencije EU za ljudska prava o implikacijama virusa korona, u Mađarskoj su vlasti stavljale crvene kartone na vrata osobe koja je bila obavezna da bude u kućnom pritvoru, a policija je redovno provjeravala da li je kod kuće. ${ }^{67}$ U skladu sa Uredbom Vlade Mađarske (2020, 41/20), u slučaju zloupotrebe bila je propisana novčana kazna u iznosu od 150,000 HUF (€ 425). Prema nalazima Agencije, novčane kazne za nepoštovanje novih mjera primjenjivale su se u većini država članica. Neke su čak primjenjivale i kazne zatvora. ${ }^{68}$

\footnotetext{
${ }^{62}$ Vidjeti: https://ec.europa.eu/transport/coronavirus-response_en, pristupljeno: 22. maj 2020. godine.

${ }^{63}$ Austrija, Belgija, Grčka, Danska (osim za avio-sabraćaj i kretanje unutar države gdje ne postoji zabrana), Holandija, Slovenija, Francuska, Finska, Švedska, Letonija.

64 “Coronavirus response: Transport measures”, European Commission, https://ec.europa.eu/ transport/transport-modes/news/2020-03-27-coronavirus-response-transport-measures _en, pristupljeno: 20. mart 2020.

${ }^{65}$ Ibid.

${ }^{66}$ Ibid.

67 "Coronavirus pandemic in the EU - Fundamental rights implications", 1 February-20 March, EU Agency for fundamental rights, Luxembourg, Publications Office of the European Union, April 2020, p. 17.

${ }^{68}$ Ibid., p. 19.
} 
Recimo, u Belgiji u skladu sa Zakonom o građanskoj bezbjednosti iz 2007, za kršenje mjere zabrane okupljanja slijedila je kazna zatvora od 8 dana do tri mjeseca. ${ }^{69}$ U Bugarskoj, u skladu sa Zakonom o izmjenama i dopunama Krivičnog zakonika koji je Narodno sobranje usvojilo 16. januara 2019. godine, za kršenje mjera koje imaju za cilj suzbijanje infektivnih bolesti propisana je kazna zatvora do pet godina. ${ }^{70}$

Vidjeli smo da, prema Povelji EU, sloboda kretanja podrazumijeva i pravo pojedinca da napusti zemlju u kojoj se nalazi. Jedan od izazova za vrijeme pandemije bio je povratak državljana blokiranih u trećim državama u domovinu. U skladu sa Mehanizmom za civilnu zaštitu, Koordinacioni centar EK za odgovor na hitne situacije djelovao je zajedno sa Evropskom službom za spoljne poslove i državama članicama. Konkretno, EK kofinansirala je troškove prevoza državaljanima EU, ali i građanima trećih država, i od izbijanja pandemije na ovaj način olakšana je repatrijacija više od 74 hiljade građana EU. ${ }^{71}$

Na osnovu opisa mjera na teritoriji država članica, a u kontekstu ispitivanja njihove opravdanosti, potrebno je analizirati donesene odluke o ograničenju prava i sloboda u odnosu na ispunjenost propisanih uslova ograničenja ljudskih prava.

Pa tako, u smislu uslova zakonitosti, u pojedinim državama članicama, restriktivne mjere podrazumijevale su izmjenu i dopunu zakona, i/ili su propisi doneseni na nivou uredbi vlada i slično. Moglo bi se smatrati da je prilikom ograničenja slobode kretanja za vrijeme pandemije virusa korona, uslov proporcionalnosti i neophodnosti u društvu u određenoj mjeri ispunjen. Nekoliko argumenata ide u prilog tome. Prvo - vidjeli smo da su donesene mjere ograničene prostorno i vremenski, srazmjerno intenzitetu zaraze i trajanju. Vlade država članica EU donosile su mjere u odnosu na svoje nacionalne potrebe, postavljajući zdravlje ljudi kao glavni prioritet. Drugo - ukoliko se uzme u obzir tvrdnja da je opšti interes nadjačao interes pojedinca, te da se radi o krizi koja prijeti da ugrozi zdravlje cjelokupnih zajednica, polje slobodne procjene moglo bi se široko postaviti.

Već smo istakli da se epidemija može smatrati „stanjem javne opasnosti”, što predstavlja uslov za potvrdu mogućnosti derogacije ljudskih prava u slučaju „državne nužde”. Iako bi derogacija u tom slučaju morala biti zasnovana na proglašenju vanrednog stanja i poslatom obavještenju generalnom sekretaru Savjeta Evrope sa istaknutim pravima od kojih se odstupa, i naznačenom vremenskom periodu u kome će se pristupiti derogaciji, u toku prvog talasa pandemije samo su tri države članice EU poslale notifikaciju.

\footnotetext{
${ }^{69}$ Ibid., p. 17.

${ }^{70}$ Ibid., pp. 23-28.

${ }^{71}$ Osim državljana EU, pomoć u repatrijaciji dobili su državljani trećih zemalja. Vidi na primjer: Island, Crna Gora, Sjeverna Makedonija, Srbija Turska. Vidjeti: https://ec.europa.eu/info/ sites/info/files/summary_tables_of_repatriation_flights_29_may_2020.pdf, pristupljeno: 20. mart 2020.
} 


\section{5) ZAKLJUČAK}

U prethodnoj analizi pokušali smo ispitati pod kojim uslovima je dopušteno ograničiti slobodu kretanja kao relativno ljudsko pravo. U slučaju kršenja odredbi kojima se propisuju uslovi ograničenja, međunarodni sudovi za ljudska prava pažljivo će ispitivati neophodnost restriktivnih mjera, primjenjujući princip proporcionalnosti i zakonitosti. Osim toga, kroz tumačenje različitih indikatora, ispitivali bi ne samo trajanje tih mjera nego bi i pokušali utvrditi da li su manje restriktivne mjere mogle dovesti do ispunjenja cilja ili postizanja istih rezultata. Suzbijanje širenja zarazne bolesti svjetskih razmjera moglo bi se smatrati srazmjerno postavljenim ciljem, a ispunjavanje uslova zakonitosti zavisiće, između ostalog, od usklađenosti donesenih zakonskih propisa u državama članicama sa Konvencijom i Poveljom EU.

Analiza mehanizama zaštite ljudskih prava pokazala je da se opravdanost ograničenja načelno mjeri stepenom usklađenosti datih mjera i propisanih uslova pod kojima se ona primjenjuju. Stepen primjene i poštovanja restriktivnih mjera, koja je u nekim državama uključivala i krivičnu odgovornost pojedinaca, posebno je pitanje i moglo bi biti predmet daljeg istraživanja.

Na pitanje - da li je ograničenje slobode kretanja bilo opravdano? - moguće je načelno pozitivno odgovoriti, pod uslovom da je to ograničenje imalo za cilj zaštitu prava na život, kao apsolutnog ljudskog prava. Međutim, za konačni zaključak potrebno je ispitati različite indikatore i okolnosti od slučaja do slučaja.

Trebalo bi uzeti u obzir i činjenicu da se radi o pandemiji koja nije zapamćena decenijama, sa očiglednim implikacijama na socio-ekonomski, društveni i pravni poredak država, što je uz nespremnost država da se suoče sa „nevidljivim neprijateljem", nedovoljno opremljenim bolnicama i slabim zdravstvenim sistemima dovelo do toga da su države bile primorane da, u cilju zaštite javnog zdravlja, donose zahtjevne i teške odluke, čije je posledice još uvijek nemoguće sveobuhvatno sagledati.

U narednom periodu očekuje se donošenje strateških odluka na nivou EU, ne samo u geopolitičkom smislu već i u oblasti zaštite ljudskih prava, u pogledu suzbijanja posledica pandemije. Na evropskom nivou za legitimnost odluka presudnu ulogu imaće Evropski parlament, zajedno sa nacionalnim parlamentima. ${ }^{72}$ Pred ESP i ESLJP zasigurno će biti predstavki s ciljem zaštite prava u periodu krize izazvane virusom korona. Ukoliko se ispostavi kršenje zagarantovanih prava, ili da je došlo do zloupotrebe načela derogacije i zloupotrebe prava, država bi trebalo da odgovora.

${ }^{72}$ Vidjeti: "The geopolitical implication of the Covid 19 pandemic", Policy Department for External Relations Directorate General for External Policies of the Union, september 2020, p. 54, dostupno: https://www.europarl.europa.eu/RegData/etudes/STUD/2020/603511/ EXPO_STU(2020)603511_EN.pdf, pristupljeno: 11. maj 2021. godine. 


\section{6) LITERATURA}

Arai-Takahashi, Yutaka, The Margin of Appreciation Doctrine and the Principle of Proportionality in the Jurisprudence of the ECHR, Antwerpen - Oxford - New York, 2001.

Barak, Aharon, "Proportionality: Constitutional Rights and their Limitations", New York Cambridge University Press, 2012.

Bernhard, Schlink, "Proportionality” in: Rosenfeld Michel and Sajó András, (eds.), The Oxford Handbook of Comparative Constitutional Law, Oxford, 2012, Oxford University Press.

Carrera, Sergio, Chun Luk, Ngo,"Coronavirus politics and their impact on EU freedoms and rule of law in the Schengen Area", CEPS Paper, No. 2020-04, 2020.

Cianciardo, Juan, "The Principle of Proportionality: The Challenges of Human Rights", Journal of Civil Law Studies, Vol. 3, 2010.

Hafner-Burton, Emilie M., et al., "Emergency and Escape: Explaining Derogations from Human Rights Treaties", in International Organization, Cambridge University Press, Vol. 65, 2011.

Krstić, Ivana, Marinković, Tanasije, Evropsko pravo ljudskih prava, Savjet Evrope, Kancelarija u Beogradu, Beograd, 2016.

Neuman, Gerald L., "Constrained Derogation in Positive Human Rights Regime", in Evan J. Criddle, (ed.), Human Rights in Emergencies, 2016.

Nina-Louisa, Arold, Lorenz, Xavier, Groussot, Gunnar Thor, Petursson, The European Human Rights Culture - A Paradox of Human Rights Protection in Europe, Leiden, 2013.

Paunović, Milan, Carić, Slavoljub, Evropski sud za ljudska prava, Pravni fakultet Univerziteta u Beogradu, Beograd, 2007.

Paunović, Milan, Krivokapić, Boris, Krstić, Ivana, Međunarodna ljudska prava, Pravni fakultet Univerziteta u Beogradu, Beograd, 2015.

Pavlović, Dejan, „Doktrine Evropskog suda za ljudska prava”, Međunarodna politika, br. 1144, 2011.

Reid, Karen, "A practitioner's guide to the European Convention on Human Rights", Thomson/Sweet \& Maxwell, London, 2015;

Stojanović, Dragan, Ustavno pravo - knjiga I, Centar za publikacije Pravnog fakulteta u Nišu, Niš, 2009.

Schabas, William, The European Convention on Human Rights: A Commentary, Oxford, 2015. 


\section{FREE MOVEMENT OF PEOPLE WITHIN “THE FIRST WAVE” OF THE CORONAVIRUS PANDEMIC IN THE EUROPEAN UNION MEMBER STATES}

Summary: The article deals with the limitation of certain human rights in order to protect human health and its justification. The paper focuses on examining the degree of restriction of freedom of movement of people from March to June 2020. In accordance with the principle of derogation from human rights, regardless of the state of urgency, restrictions must meet the requirements of legality, proportionality and necessity in a democratic society. The author examines the conditions of restriction from the aspect of correlation of the principles on which the concept of human rights is based, primarily the principle of limitation and the principle of prohibition of Abuse of Rights, as well as their derogation as a special kind of limitation. The author examines freedom of movement of people during the current pandemic, relating to the implementation of restrictive measures imposed within the EU Member States and evaluates their justification by the public interest.

Key words: coronavirus, Human Rights protection, freedom of movement, European Union, limitations of freedom, restrictive measures. 